\title{
ODNOS MED RABO TAL IN NAKLONOM POVRŠJA
}

Primeri iz predalpskega sveta v Sloveniji v letih 1826 in 1988

\author{
Marjan Bat*
}

IZVLEČEK

UDK 911.2:332.3(497.12)"1826-1988"

V clanku žclimo prikazati spremembe $\mathbf{v}$ odnosu med rabo tal in nakloni površja. Uporabljeni podatki so rezultat proucevanja treh manjæih območij v predalpskem hribovju. Sodimo, da je bilo, glede na nagib povrక̌ja, opušcanje kmetijskih povrక̌in pretirano.

ABSTRACT

UDC 911.2:332.3(497.12)"1826-1988"

RELATION BETWEEN LAND USE AND SURFACE INCLINATION

The article deals with relations between land use and surface inclination. The data discussed are the result of the investigation of the three areas in the Subalpine Hills of Slovenia. In regard of surface inclination it is obvious that a to big part of the farming land was abandoned.

\section{UVOD}

V SR Sloveniji so družbenoekonomske spremembo po drugi vojni povsem spremenile vlogo kmetijstva, dotlej ene bistvenih gospodarskih panog. $V$ hribovju se je క̌tevilo prebivalcev hitro zmanjšcvalo. Ob tem je prißlo do opušanja in manj intenzivne rabe kmetijskih povrß̌n (Medved, 1970; Vrił̌cr, 1987). Zal zemljiß̌ki kataster dokumentira novonastale razmcre netoxno in $\mathrm{z}$ zamudo.

V Clanku želimo prikazati, kako se prevrednotenje prirodnogeografskih razmer odraža v spremenjenem odnosu med nagnjenostjo povrłja in rabo tal. Uporabljeni podatki so rezultat proučevanja treh manjふ̧ih obmoxij v predalpskem hribovju - Martinj Vrha (500 ha) na severnem poboðju Koprivnika v Škof jeloß̌kem hribovju, Tiroska (575 ha) v povirju Zadrecke doline in Rakitovca ( 375 ha) na razvodnem slemenu med Črnim Grabnom in Tuhinjsko dolino. V celoti smo obdelali 1450 ha zemljišc, ki predstavijajo vzorčno obmocje predalpskega hribovja.

Za proǔcevana obmox ja smo izdelali preprost geografski informacijski sistem (GIS), katerega osnova je bila celica s površno 0,25 ha (stranica $50 \mathrm{~m}$ ). Za potrebe analize je bila vsaka celica označna s podatkom o povprečncm naklonu (izračunano iz digitalnega modela reliefa - DMR 50) in rabi tal. Podatke o rabi tal za preteklo stoletje smo povzcli po mapah franciscejskega katastra, današnje stanje pa smo dolocili s terenslim delom in letalskimi posnetki.

* Mag., univ. asis., Oddelek za geografijo, Filozofska fakuiteta, 61000 Ljubljana, Aškerčeva 12, YU. 


\section{RABA TAL LETA 1826 IN 1988}

Pri ocenjevanju podatkov, ki jih navajamo, je treba upostevati, da smo skuSali z izbranimi obmożi zajeti predvsem kmetijske površine zaselkov in samotnih kmetij. Glede na to vzorčno območje ni tipično za predalpsko hribovje, saj to, zajeto v celoti, nima tolikšnega deleža kmetijskih povrక̌n. Menimo pa, da vzorec zadovoljivo predstavlja gosteje poseljene predele hribovja. Ti so, zaradi spremenjenega razmerja med kmetijskimi in gozdnimi površnami, dobili novo podobo. Na to nas opozarjajo podatki prikazani v TABELI 1.

TABELA 1.: Spremembe v povrß̌inah zemljiških kategorij (za celotno vzorčno obmoxje):

TABLE 1.: Changes of areas of land use categories (for the complete sample):

\begin{tabular}{|c|c|c|c|c|c|}
\hline $\begin{array}{l}\text { leto } \\
\text { ycar }\end{array}$ & $\begin{array}{l}\text { njiva } \\
\text { arable }\end{array}$ & $\begin{array}{l}\text { travnik } \\
\text { meadow }\end{array}$ & $\begin{array}{l}\text { pašnik } \\
\text { pasture }\end{array}$ & $\begin{array}{l}\text { gozd } \\
\text { wood }\end{array}$ & $\begin{array}{l}\text { ostalo } \\
\text { other }\end{array}$ \\
\hline 1826 ha & 295 & 219 & 290 & 622 & 23 \\
\hline$\%$ & 20.3 & 15.1 & 20 & 42.9 & 1.6 \\
\hline 1988 ha & 50 & 368 & 54 & 947 & 31 \\
\hline$\%$ & 3.4 & 25.4 & 3.7 & 65.3 & 2.1 \\
\hline $\begin{array}{l}\text { indeks } \\
(1988 / 1826)\end{array}$ & 17 & 168 & 18 & 152 & 134 \\
\hline
\end{tabular}

Podoba celote dovolj dobro odraža spremembe do katerih je prišlo na posameznih obmoxjih. V okvirih vaškega zcmljiš̌a se je delež njiv mox̌no zmanjక̌l (glej tudi Mcze, 1986), na njegov račun pa se je povecal delež travnikov. Da bi trditev dokazali, smo izbrali le tiste celice, ki so bile $\mathrm{v}$ zacetku preteklega stoletja $\mathrm{v}$ celoti pod njivami in preverili, kakకna je bila njihova raba leta 1988. Rezulati so prikazani v TABELI 2.

TABELA 2:: Raba nekdanjih njivskih povrsin (leti 1988 in 1826)*:

TABLE 2.: Land use of the former arable land (years 1988 and 1826)*:

$\begin{array}{lccllll}\text { Martinj vrh } & \begin{array}{l}\text { skupaj } \\ \text { total }\end{array} & \begin{array}{l}\text { njiva } \\ \text { arable }\end{array} & \begin{array}{l}\text { travnik } \\ \text { meadow }\end{array} & \begin{array}{l}\text { pašnik } \\ \text { pasture }\end{array} & \begin{array}{l}\text { gozd } \\ \text { wood }\end{array} & \begin{array}{l}\text { ostalo } \\ \text { other }\end{array} \\ \text { ha } & 21.7 & 1.9 & 17.0 & 2.0 & 0.4 & 0.4 \\ \begin{array}{l}\text { Rakitovec } \\ \text { ha }\end{array} & 99.8 & 8.7 & 78.3 & 9.2 & 1.8 & 1.8 \\ \% & 57.3 & 19.1 & 33.9 & 0.4 & 3.5 & 0.4 \\ \text { Tirosck } & 100 & 33.3 & 59.2 & 0.7 & 6.1 & 0.7 \\ \text { ha } & & & & & & \\ \text { \% } & 50.3 & 5.8 & 36.6 & 5.2 & 1.6 & 1.1 \\ \text { skupaj (total) } & 100 & 11.5 & 72.8 & 10.3 & 3.2 & 2.2 \\ \text { ha } & 129.3 & 26.8 & 87.5 & 7.6 & 5.5 & 1.9 \\ \% & 100 & 20.7 & 67.7 & 5.9 & 4.3 & 1.4\end{array}$

- upoštevane so le celice, ki so bile v celoti pod njivami.

* - only grids completly occupied by arable land are examined. 
Na vsem obravnavanem obmoxju je bilo po podatkih franciscejskega katastra od 5800 -ih celic 517 takih (129 ha, $8.9 \%$ ), ki so bile v celoti pod njivami. Leta 1988 je bil na istih zemljiscih le se $20 \%$ njiv, kar $67 \%$ pa je bilo zatravljenih. Gozd se danes pojavlja na veð kot 50 -ih celicah, vendar jih le izjemoma preraš̌a vsaj do polovice.

Pašniki so postali nepomembna zemljiska kategorija. Na osnovi podatkov za 187.5 ha povrßin, ki so bile na franciscejskem katastru prikazane kot pašnik, lahko sklepamo, da jih je vexino zarasel gozd.

TABELA 3.: Raba nekdan jih pašnikov (leti 1988 in 1S26)*:

TABLE 3.: Land use of the former pastures (years 1988 and 1826)*:

\begin{tabular}{|c|c|c|c|c|c|c|}
\hline 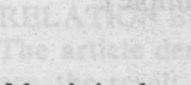 & $\begin{array}{l}\text { skupaj } \\
\text { total }\end{array}$ & $\begin{array}{l}\text { njiva } \\
\text { arable }\end{array}$ & $\begin{array}{l}\text { travnik } \\
\text { meadow }\end{array}$ & $\begin{array}{l}\text { paŠnik } \\
\text { pasture }\end{array}$ & $\begin{array}{l}\text { gozd } \\
\text { wood }\end{array}$ & $\begin{array}{l}\text { ostalo } \\
\text { other }\end{array}$ \\
\hline Martinj vrh & & & & & & \\
\hline $\begin{array}{l}\text { ha } \\
\%\end{array}$ & $\begin{array}{l}154.0 \\
100\end{array}$ & $\begin{array}{l}0.5 \\
0.3\end{array}$ & $\begin{array}{l}16.5 \\
10.7\end{array}$ & $\begin{array}{l}1.8 \\
1.2\end{array}$ & $\begin{array}{r}133.2 \\
86.5\end{array}$ & $\begin{array}{l}2.0 \\
1.3\end{array}$ \\
\hline Rakitovec & & est & & & & \\
\hline ha & 31.2 & 0.0 & 2.5 & 0.0 & 28.5 & 0.2 \\
\hline $\begin{array}{l}\% \\
\text { Tirosck }\end{array}$ & 99.9 & 0.0 & 8.0 & 0.0 & 91.3 & 0.6 \\
\hline ha & 2.3 & 0.0 & 0.7 & 0.5 & 1.0 & 0.1 \\
\hline $\begin{array}{l}\% \\
\text { skupaj (total) }\end{array}$ & 100 & 0.0 & 30.4 & 21.7 & 43.5 & 4.3 \\
\hline ha & 187.5 & 0.5 & 19.7 & 2.3 & 162.7 & 2.3 \\
\hline$\%$ & 100 & 0.3 & 10.5 & 1.2 & 86.8 & 1.2 \\
\hline
\end{tabular}

- - upostevane so le ceiice, ki so bile leta 1826 v celcti pod pašniki.

- - only grids completly occupied by pastures in $1 \$ 26$ are examined.

Izjemo predstavlja Tirosek, kjer je po franciscejskem katastĩu na obravnavanem ozemlju le 2,3 ha pašnikov (TABELA 3.). Kmetje so pasli na višji Menini in Kašni planini (Kranjska reber). Za razliko od Martinj Vrha in Rakitovca, kjer so pašo bolj ali manj opustili, pa se je v Tiresku v zadnjem casu mołno razmahnila. $Z$ urejanjem čredink je meja med tipiennimi travniki in pašniki zabrisana. Zato so bila pri kartiranju rabe tal kot pasniki opredeljena tista zemljiša, kjer je travna rußa raztrgana, kjer je svet skalnat in ga kmetje ne kosijo. Tovrstnim pašnikom je $v$ celoti namenjeno zemljišcc 61-ih celic (15.25 ha). Večinoma so bile to v preteklem stoletju njive in travniki (TABELA 4.). 
TABELA 4.: Nekdanja raba zemljišc, ki so danes pod pašniki (leti 1826 in 1988)*:

TABLE 4.: Former land use of the areas occupied today by pastures (years 1826 and 1988)*:

$\begin{array}{llllll}\text { skupaj } & \text { njiva } & \text { travnik } & \text { pašnik } & \text { gozd } & \text { ostalo } \\ \text { total } & \text { arable } & \text { meadow } & \text { pasture } & \text { wood } & \text { other }\end{array}$

$\begin{array}{lllllll}\text { Tirosek } & & & & & \\ \text { ha } & 15.3 & 7.1 & 5.6 & 0.8 & 1.6 & 0.2 \\ \% & 99.9 & 46.4 & 36.6 & 5.2 & 10.4 & 1.3\end{array}$

- - upoštevane so le celice, ki so bile leta 1988 v celoti pod pašniki.

* - only grids completly occupied by pastures in 1988 are examined.

Delež gozda se je povsod znatno poveðal. Iz zgornjih tabel je razvidno, da se je gozd కiril predvsem na pašnike in manj na ostale kmetijske povrక̌ine. Razmerje med kmetijskimi površnami in gozdom, ki je bilo $\mathrm{v}$ preteklem stoletju (velja za celotno obravnavano obmoxje) $1.3: 1 \mathrm{v}$ korist prvih, je danes $0.5: 1 \mathrm{v}$ korist gozda.

\section{ZEMLJIŠKE KATEGORIJE IN NAKLON POVRŠJA}

V hribovju je naklon površja gotovo med pomembnejsimi dejavniki, ki odloðajo o razporeditvi zemljiskih kategorij (Jeršic, Pleško, 1975). Meje, ki jih doloða pa niso nckaj, kar bi veljalo za zmeraj (Medved, 1970). Obe trditvi v precejšnji meri potrjujejo podatki, ki so prikazani v TABELI 5. Meje razredov povzemamo po literaturi (Natek, 1983).

TABELA 5:: Delež obdelovalnih povrŠin po naklonskih razredih (v oklepaju delež njiv glede na celoto):

TABLE 5.: The share of the cultivated land (arable land and meadows) by inclination classes (in parenthesis - arable land only):

1826

$54.5 \%(36.6)$,
$53.3 \%(37.5)$,
$38.9 \%(24.1)$,
$17.1 \%(9.4)$,
$6.5 \%(1.9)$,

1988

nakloni od $7-12^{\circ}$

nakloni od $0-6^{\circ}$

nakloni od $13-20^{\circ}$

nakloni od $21-32^{\circ}$

nakloni nad $33^{\circ}$
$45.0 \%(6.0)$,

$42.1 \%(10.4)$,

$32.6 \%$ (1.8),

$14.4 \%(0.2)$,

$4.5 \%(0.0)$.

Glede na delež njiv in travnikov izstopajo v obeh obdobjih zemijišca z nakloni do $12^{\circ}$. Bolj nagnjen svet $\left(7-12^{\circ}\right)$ je naviđez celo ugodnejši. Na njem je delež obdelovalnih povrక̌in ve`jji, hkrati pa se je relativno manj skræil. Razliko gre deloma pripisati 
temu, da je velik delež ravnega sveta $v$ dnu grap ali na slemenih, torej v legah, ki mikroklimatsko in pedolosko niso ugodne. Nekoliko je slika skrivljena tudi zaradi glajenja rcliefa (DMR prikaže ravnino $v$ ozki grapi in na grebenu). Krそenje obdelovalnih povrక̌in na najvęjih strminah se ne zdi pretirano. Moramo pa upoštevati, da se je prav pri teh naklonih najbolj spremenilo razmerje med travniki in njivami (glej tudi GRAFIKONA 1. in 2.).

V TABELAH 6. in 7. so prikazane spremembe povpreðnih naklonov pri zemljišcih namenjenih posameznim kategorijam. Do njih je prišlo ob spremembi rabe tal.

TABELA 6.: Povprecni naklon zemljiš namenjenih posameznim kategorijam $\left(\mathrm{v}^{0}\right.$ ): TABLE 6.: Average inclination of the land use categories (in ${ }^{\circ}$ ):

$\begin{array}{llllll}\text { leto } & \begin{array}{c}\text { Martinj } \\ \text { year }\end{array} & \text { Rakitovec } & \text { Tirosek } & \begin{array}{c}\text { skupaj } \\ \text { total }\end{array} \\ \begin{array}{l}\text { njiva } \\ \text { arable }\end{array} & 1826 & 17,9 & 15,6 & 14,5 & 15,8 \\ \text { travnik } & 1826 & 16,7 & 12.0 & 13,5 & 13,3 \\ \text { meadow } & 1988 & 19,9 & 16,1 & 14,3 & 16,4 \\ \text { pašnik } & 1826 & 18,9 & 16,1 & 14,3 & 16,4 \\ \text { pasture } & 1988 & 22,5 & 20,0 & 17,1 & 21,3 \\ \text { gozd } & 1826 & 19,8 & 20,4 & 13,8 & 15,6 \\ \text { wood } & 1988 & 24,3 & 19,7 & 20,3 & 21,1 \\ & & 23,6 & 19,8 & 19,6 & 21,1\end{array}$

V okviru posamezne kategorije so bilc upostevane celice na katerih se kategorija pojavi vsaj na $x$ ctrtini površine $(0.06$ ha). Ker je pestra struktura rabe tal na $z$ cmlji-

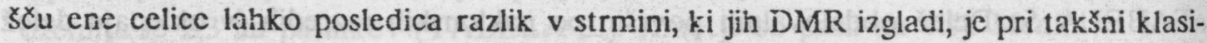
fikaciji zabrisana povezava med naklonom in razporeditvijo zemljiskih kategorij. To potrjujejo podatki v TABELI 7., ki prikazujejo naklon za celice, na katerih se pojavIja ena sama kategorija (velja za celotno vzorěno obmoxje). Takšen izbor je za prikazovanjc odnosa med dejavnikoma primernejši.

TABELA 7.: Povprečni naklon celic $\left(v^{\circ}\right)$, ki so glede na rabo tal homogene (stevilo celic v oklepaju):

TABLE 7:: Average inclination of grids (in ${ }^{\circ}$ ) with the uniform land use (in parenthesis - number of grids):

$\begin{array}{lcccc}\begin{array}{l}\text { leto } \\ \text { year }\end{array} & \begin{array}{l}\text { mjiva } \\ \text { arable }\end{array} & \begin{array}{l}\text { travnik } \\ \text { meadow }\end{array} & \begin{array}{l}\text { pašnik } \\ \text { pasture }\end{array} & \begin{array}{l}\text { gozd } \\ \text { wood }\end{array} \\ 1826 & 13.8(517) & 17.7(292) & 23.8(748) & 21.9(2061) \\ 1988 & 8.6(50) & 15.5(742) & 14.4(97) & 22.3(3187)\end{array}$


Ob zacetku preteklega stoletja so bile samooskrbne kmetije prisiljene velik delež zemljiš namenjati njivam. Te so se Sirile tudi na strminah izpostavljenih eroziji. Zaradi pretiranega obsega njiv je bilo travnikov manj. Zivinoreja je $v$ večji meri izkorišcala pašnike, ki so segali na prestrma zemljisča. Presenetljiv je podatek, da je bil povprečni naklon pašnikov večji od povpređ̌nega naklona zemljiš poraslih z gozdom (TABELA 7.). Na osnovi proužcnih obmocij bi sodili, da je o razporeditvi pašnikov odlođalo lastništvo (pasli so na srenjski zemlji - na gmajni, ne pa v privatnih gozdovih; ZAP, 1970). Ugodno je bilo, ce je bila pasa blizu kmeckega doma in je imela živina dostop do vode, medtem ko naklon pašnika ni bil tako pomemben. Na proucevanih obmőjjih naletimo pri razporeditvi pašnikov vsaj na dve obliki:

1.) razdrobljeni pasnniki - oblika izrazito prevladuje v Tirosku, kjer so pašniške parcele na ožjem vaškem zemljišu majhne in malostevilne. Franciscejski kataster jih oznacuje ponekod $v$ colinskem dnu (log ob Dreti), v strminah nad kmexkim domom, v bregovih grap, po katerih so pogosto potekale tudi meje med celki. Ker pašniki niso segali na vex̌je strmine, paša glede na naklon ni bila pretirana (TABELA 6.). Skupnih pašnikov, ki bi jim lahko namenili le slabši svet, na ožjem vaškem zemljišcu ni bilo. Kmet je so imeli zanje dobro nadomestilo na Menini in Kašni planini.

2.) pašniški kompleksi na manj kvalitetnih zemljišcih - srečamo jih na Rakitovcu in Martinj Vrhu, kjer prevladajo (kar zadeva površine) nad razdrobljenimi pašniki. $\mathrm{N}$ jihov obseg je dolocen $\mathrm{z}$ obsegom srenjske zemlje. Ta se je chranila $\mathrm{v}$ vlažnih in tesnih grapah in na strmih bregovih. Franciscejski kataster kaže, da so bili pašniki porasli z drevjem. Na njegovi osnovi pa ni mogoðe presoditi v kolikšni meri. Podatki o povprecnih naklonih (TABELA 6.) dajejo slutiti, da je bila pasa pretirana. Na Martinj Vrhu je biio 31 ha pašnikov, katerih naklon je presegal $32^{\circ}$.

Obdobje tako intenzivnega izkorišcanja zamljišc, ki je doseglo vrhunec ob koncu pretcklega stoletja, je bilo zakljuðeno šle po drugi svetovni vojni (Vrišer, 1987). Med drugim je pustilo sledove $\mathrm{v}$ drobni reliefni oblikovanosti in v spremenjeni pedoloski odeji. Na nekdanje njive opozarjajo antropogene terase, ki so nastajale na parcelnih mejah (odori) in velike razlike v kvaliteti (dcbelini, kamnitosti) prsti. Ponekod je bila prst odnešena do te mere, da so nekdanje njivske parcele danes opuščne. Na pašnike opozarja koluvij, ki se je akumuliral v grapah in na poiicah, ob vznožju strmih pobocij, in ponekod prekril starejše prsti na pobočnem grušu. $V$ tej mešanici prsti in grušca prihaja pogosto do usadov, zlasti tam, kjer je zakrila izvire in zatrpala manjæa povirja.

Literatura pogosto omenja vplive prevex intenzivne rabe tal na erozijo in akumulacijo potokov ter hidrografske in klimatske znaxilnosti. Toda konkretnih prouxitev je malo. 
Podatki za leto 1988 kažejo, da se je najobCutneje spremenil povprexni naklon površn namenjenih pašnikom. To je posledica popolne premene zemljišc, ki jih izkorišajo.

Bistveno manjsi je tudi povprecni naklon sedanjega njivskega sveta. Nekdanji njivski kompleksi so se ohranili na zemlji, kjer je mogoca strojna obdelava - to je na najbolj zložnem svetu (npr.: Rakitovec). Od nekdanjih njivskih kompleksov na večjih strminah so se ohranile le njivske krpe. Te $\mathrm{z}$ vidika erozije prsti niso tako problematixne.

Povprexni nagib travnikov se je zmanjłal predvsem na rađun ozelenjevanja njiv. Tudi pri spravilu sena večino dela opravijo s stroji, ki š zmorejo tolikšne naklone.

\section{ZAKLJUČEK}

Zdi se, da so razmere, v katerih se je znašlo hribovsko kmetijstvo, povzročile, da se danaŠnja raba tal $v$ večji meri sklada $z$ možnostmi, ki jih nudi površje glede na strmine. Celo vec. Marsikje je prišlo do pretiranega opušcanja kmetijskih površin - iz ene skrajnosti smo zašli v drugo. To se najoxitneje kaže pri pašnikih, ki bi mogli in morali imeti vecji pomen v gospodarstvu hribovskih kmetij.

GRAFIKON 1. IN 2. Odnos med rabo tal in naklonom - v letih 1826 in 1988 (1. njiva;

2. travnik; 3. pašnik; 4. gozd).

FIGURE 1. AND 2. The relation between land use and surface inclination - in the year 1826 and 1988 (1. arable land; 2. meadow; 3. pasture; 4. wood land). 


\section{LITERATURA:}

Bat M., 1989. Fizixna geografija gorskega sveta. Magistrska naloga. Knjižnica Oddelka za geografijo, Ljubljana.

Gams I., 1986. Osnove pokrajinske ekologije. Ljubljana.

Jerß̌i M., Pleško M., 1975. Zasnova uporabe prostora SR Slovenije. Kmetijstvo (izvlecek iz osnovnega gradiva). Zavod SRS za RPP. L jubljana.

Kladnik D.,1982. Drustveno-ckonomski aspekti i iskorišavanje zemljista u SR Sloveniji. Geographica Iugoslavica, Novi Sad.

Medved J., 1970. Spremembe v izrabi zemljiša in preslajanje kmeckega prebivalstva v Sloveniji v zadnjih dveh desetlet jih. Geografski vestnik XLII, Ljubljana.

Meze D., 1969. Hribovske kmetije v vzhodnem delu Gornje Savinjske doline. Geografski zbornik 11, Ljubljana.

Meze D., 1980. Hribovske kmetije v Gornji Savinjski dolini po letu 1967. Geografski zbornik 19/1, L jubljana.

Meze D., 1986. Hribovske knetije v Selski dolini. Lołki razgledi 33, Škof ja Loka.

Natek K., 1983. Metoda izdelave in uporabnost splošne geomorfološke karte. Magistrska naloga, Knjižnica Oddelka za geografijo, Ljubljana.

Natck M., 1985. Prebivalstvo v gospodinjstvih z zemljišo posestjo v SR Sloveniji v letu 1981. Geografski vestnik LVII, Ljubljana.

VriŠer I., 1987. Spremembe v zemljiskkih kategorijah v Sloveniji. Geografski vestnik LIX, L jubljana.

Vriß̌er I., 1988. Živinore ja v SR Sloveniji. Geografski vestnik LX, Ljubljana. ZAP, 1970. = Zgodovina agrarnih panog, 1.zvezek. SAZU, Ljubljana. 


\section{RELATION BETWEEN LAND USE AND SURFACE INCLINATION}

Examples from Subalpine Hills in Slovenia in the years 1826 and 1988

After the World War II the status of farming, which was one of the basic branches of economy until then, has changed essentially in Slovenia. The most evident changes have taken place in the highlands where depopulation occurred and it resulted in different evaluation of natural geographic conditions. We are going to present these changes from the aspect of surface inclination of the land used for farming. The data discussed are the results of the investigation of three regions from the Subalpine Hills in Slovenia (Martinj Vrh in the Selška dolina - 500 ha., Rakitovec in the Posavsko Hills - 375 ha., Tirosek in the Zadrecka dolina - 575 ha.). We have elaborated for them a simple geographic information system (GIS), the basis of which is a grid with the area of 0.25 ha. $(50 \times 50 \mathrm{~m})$.

From the data shown in the TABLES 1.,2. and 3. it is evident that the changes of land use are the consequences of transformation of fields into meadows and of pastures into forests. In Tirosek where more modern type of pasturing is in use, the former fields and meadows have been turned to pastures (TABLE 4.). The ratio between farming areas and the forest has been changed from former 1.3: 1 in behalf of farming areas to $0.5: 1$ in behalf of forests.

The surface inclination has, of course, a strong influence on the location of land use categories. However, man has not always taken into account to the same extent the limits which are imposed by inclination. Data shown in TABLE 5. give evidence for this statement. There are more areas of cultivable land on the slightly inclined slopes than on the flat land. It results from improved microclimatic and pedologic conditions. Partiy this is also the result of relief leveiling which, in spite of a high grid density /Digital Relief Model - DMR 50/, cannot be excluded. Anyhow, with the growth of inclination the intensity of land use is being diminished.

The rates of changes in inclination are shown in the TABLE 6. (all the grids where individual category occurs are examined) and in the TABLE 7. (the grids with only one land use category are cxamined).

The data shown that from the aspect of inclination, the land use in the year 1826 was excessive. Since it persisted until mid-20th century it has left traces also in the relief forms (antropogenic terraces, landslides, erroded and colluvial slopes). As concerns this problem, modern land use is in better accordance with the given conditions. We have also come to the conclusion that a to big part of the farming land was abandoned in last decades. 